\title{
Analysis of Factors that Influence Communities in doing Re-Visit to Outpatient Installation of Praya Hospital Central Lombok
}

Dhandi Hidayatullah ${ }^{1}$,
Nurwijayanti $^{2}$, Siti Farida

${ }^{2}$ Magister of Health Study
Program of Institut Ilmu Kesehatan
STRADA Indonesia
${ }^{2}$ Lecturer of Institut Ilmu
Kesehatan STRADA Indonesia
Email:
dandi.pjrtc@gmail.com

Received : October 12, 2019

Accepted : February 13, 2020

Published : May 10, 2020

\begin{abstract}
The potential of the hospital includes all the resources owned including all hospital resources as input, management as a process and health service products as an outcome are expected to be able to sell the products produced. In order to remain competitive, the products produced must be of quality and in accordance with the criteria of community needs. In determining target consumers, hospitals need to understand consumer behavior in the decisionmaking process. The purpose of the study was to analyze the factors that influence the community in conducting outpatient visits at Praya Hospital. The design was Cross Sectional. Population was all patients at the outpatient installation of 1,662 patients. The sample size was 326 respondents using simple random sampling technique. Independent variables of research ware hospital facilities, hospital services, ease of information, ease of access (distance, transportation). The dependent variable was re-visit the outpatient installation. Data was collected using a questionnaire, then the data were analyzed using the ordinal regression test with a significance level of $\alpha \leq 0.05$. The results showed that the majority of respondents revealed good hospital facilities as many as 179 respondents (54.9\%), good hospital services as many as 184 respondents (56.4\%), ease of good information as many as 210 respondents (64\%), easy access (distance and transportation) as many as 191 respondents $(58.6 \%)$, re-visit the outpatient installation as many as 182 respondents $(55.8 \%)$. The results showed that there were influences of hospital facilities $(p=0,000)$, hospital services with $(p=0.036)$, ease of access $(p=0.023)$, and ease of information ( $p$ $=0.001)$ on revisiting outpatient installations. Hospitals with facilities, easy access and easy information services can increase patient satisfaction so that patients can return to the hospital to make a repeat visit to the outpatient installation.
\end{abstract}

Keywords: Facilities, services, easy access, information, repeat visits

This is an open-acces article distributed under the terms of the Creative Commons Attribution-ShareAlike 4.0 International License. 


\section{INTRODUCTION}

Hospital is one of the means of health efforts that provide health services to the community has a strategic role in accelerating the improvement of the degree of public health as a health development goal. Therefore, hospitals are always required to provide quality services in accordance with established standards. The government in this case issued Kepmenkes No.129 / 08 which states that minimum hospital service standards must include standards for medical services, support services, nursing services, poor family services and hospital management standards, which consist of human resource management, financial management, hospital information system, infrastructure and service quality management (Kepmenkes, 2012).

The potential of the hospital includes all the resources owned including all hospital resources as input, management as a process and health service products as an outcome are expected to be able to sell the products produced. In order to remain competitive, the products produced must be of quality and in accordance with the criteria of community needs. In determining target consumers, hospitals need to understand consumer behavior in the decision-making process (Dumpapa, 2010). The service process provided starts from the registration stage until the patient gets treatment and healing. The form and procedure of services provided by the hospital is tailored to the type of patient who is treated. Today, the types of patients who go to each hospital are generally categorized as patients with health insurance or general patients.

Basically, the community began to be smart in accessing health services, they began to demand good service in government institutions, where at the time they only hoped for good service to private institutions. Today government institutions are public institutions that must provide good servants to the community as a form of responsibility. Every leader of government agencies is always required to improve the quality of service of the agencies they lead, especially agencies directly related to public services such as hospitals and health centers (Alamsyah 2017). From the marketing perspective itself, in such a competitive situation in order to get out as winners the hospital management is required to be able to design and implement a marketing strategy that is able to create, maintain, and increase customer satisfaction in this case, so that it can ultimately influence patient decision making the product offered by the hospital.

One form of health service owned by the hospital is outpatient services. Outpatient service is a health service that is very important because it is the beginning of patients to utilize health services before they utilize other health services such as radiology, laboratory, pharmacy, hospitalization etc. The first impression that patients get when utilizing health care facilities is in outpatient services. In this case, good outpatient services can improve the image of the hospital. Therefore, to improve one of the hospital profit centers, outpatient management must receive special attention. Outpatient services are expected to provide professional health services, both from resources, service flow, and ease of information (Riyadi, 1997 in Maslina, 2015).

Committee on Quality Health in America (2012) in hospital competition it is necessary to develop services that are oriented towards meeting consumer needs. One of the things that must be considered in the health care system in the 21 st century is patient-centered health services, which pay attention to individual desires, needs, patient values, and ensure that the values given by patients direct all treatment decisions.

Patient visits that continue to decline indicate that the marketing strategy implemented by the Hospital is not going well so that the interest of patients to make repeat visits is low. Based on marketing theory, interest in revisiting is influenced by various factors, namely product quality, cost, promotion, human resources, place, and process. From a number of surveys conducted which caused the decline in interest in patient revisits are factors of human resources (doctors), costs, promotions, and services (Anggraeni, Nila Vicky, 2013).

The results of preliminary data collection on data on outpatient hospital services in Praya Hospital in 2017 obtained from the medical record section of Praya Hospital numbered 32,344 patients where the number of repeat visits in 2017 was 23,275, while the number of new visitors in 2017 was 9,069 patients. whereas in January to July 2018 there were 16,570 patients, where the number of old patients in January-July 2018 was 11,637 patients, while there were 4,933 new patients and if seen from the number of visits each month there were irregularities in terms of numbers repeat visits, sometimes increasing and also sometimes decreasing and if it is not immediately detected in the cause and finding 
a solution from it does not rule out the possibility that in the future the number of visitors in Praya Hospital will continue to decrease.

Based on the results of a preliminary study of researchers with patients in an outpatient installation. Interviews were conducted by researchers on 20 patients in outpatient installations. From these results, 7 people stated that they would reuse RSUD services and 3 people could not decide to reuse or not service at Praya Hospital. While 10 patients said they would consider the service or continuation of treatment elsewhere, because patients felt less comfortable with the facilities and services received. Most of the patients always complained about the lack of supporting facilities in the polyclinic and the services provided by hospital staff, as well as patients complaining about the information provided from the hospital which they felt was still lacking and access to the hospital. And researchers also conduct interviews with employees in outpatient installations, they always strive to provide maximum service and try to behave in a friendly, polite, touching, empathetic and respectful manner to clients and families. But they also admit that if the activities or activities in the room are quite a lot, it can be when the client is many or not, they feel tired and usually sensitive and this can be reflected from the verbal and non-verbal expressions that seem to be unfriendly to the patient.

Of course it is not beneficial for the hospital and if left alone will affect the hospital's performance in the future. The patient's discomfort with the quality of service cannot be allowed to continue continuously, as well as the facilities in the hospital especially those in outpatient installations must be repaired so that the community or patients who come feel satisfied and comfortable, because in the future if they can continue to be reduce the interest of patients to choose treatment at the hospital. Patients or prospective patients tend to be reluctant to stay long if they feel uncomfortable and are treated unprofessionally. For patients who have received service at the hospital, whether or not he lives can depend on the illness he is experiencing. But the low quality of services provided can also reduce the interest of other prospective patients to choose to use services at the Hospital. Patients in general prefer to be treated in hospitals that provide good service and are supported by complete access and facilities from medical facilities and their support (Suryadi, Sofian 2010). The purpose of this study was to analyze the factors that influence the community in conducting outpatient visits at Praya Hospital.

\section{METHODS}

The design was Cross Sectional. Population was all patients at the outpatient installation of 1,662 patients. The sample size was 326 respondents using simple random sampling technique. Independent variables of research ware hospital facilities, hospital services, ease of information, ease of access (distance, transportation). The dependent variable was re-visit the outpatient installation. Data was collected using a questionnaire, then the data were analyzed using the ordinal regression test with a significance level of $\alpha \leq 0.05$.

\section{RESULTS}

\section{Subject Characteristics}

Table 1. The characteristics of the respondents in this study included age, sex, education, occupation, hospital facilities, hospital services, ease of information, ease of access and re-visit to the hospital.

\begin{tabular}{llll}
\hline No & Characteristics & $\mathbf{\Sigma N}$ & $\mathbf{\Sigma \%}$ \\
\hline 1 & Age (year) & & \\
& $<20$ & 29 & 8,9 \\
& $20-30$ & 65 & 12,9 \\
& $31-40$ & 91 & 27,9 \\
& $>40$ & 141 & 43,3 \\
\hline 2 & Gender & & \\
& Man & 128 & 39,3 \\
& Female & 198 & 60,7 \\
\hline 3 & Education & & \\
& Doesnt school & 33 & 10,1 \\
& Elementary school & 32 & 9,8 \\
& Junior high school & 30 & 9,2 \\
& Senior high school & 179 & 54,9 \\
\hline \hline
\end{tabular}


University

\begin{tabular}{|c|c|c|c|}
\hline 4 & Occupation & & \\
\hline & Goverment employees & 19 & 5,8 \\
\hline & Private & 148 & 45,4 \\
\hline & entrepreneur & 24 & 7,4 \\
\hline & Housewife & 107 & 32,8 \\
\hline & Does not work & 28 & 8,6 \\
\hline 5 & Hospital facilities & & \\
\hline & Not good & 147 & 45,1 \\
\hline & Well & 179 & 54,9 \\
\hline 6 & Hospital service & & \\
\hline & Not good & 142 & 43,6 \\
\hline & Well & 184 & 56,4 \\
\hline 7 & Ease of information & & \\
\hline & Difficult & 116 & 35,6 \\
\hline & Easy & 210 & 64,4 \\
\hline 8 & Ease of access & & \\
\hline & Difficult & 135 & 41,4 \\
\hline & Easy & 191 & 58,6 \\
\hline 9 & Re-visit to the hospital & & \\
\hline & Not & 144 & 44,2 \\
\hline & Yes & 182 & 55,8 \\
\hline & Total & 326 & 100 \\
\hline
\end{tabular}

\section{STATISTICAL TEST RESULTS}

Table 2.Multivariate analysis with partial logistic regression

\begin{tabular}{llllllll}
\multicolumn{8}{c}{ Variables in the Equation } \\
\hline Step 1 $^{\text {a }}$ & B & S.E. & Wald & Df & Sig. & Exp(B) \\
\cline { 2 - 9 } & Facility_RS & 1,910 &, 532 & 12,883 & 1 &, 000 & 6,755 \\
\cline { 2 - 9 } & Service_RS & 1,162 &, 555 & 4,382 & 1 &, 036 & 3,197 \\
\cline { 2 - 9 } & Ease_Access & 1,192 &, 524 & 5,174 & 1 &, 023 & 3,293 \\
\cline { 2 - 8 } & Ease of Information & 2,097 &, 634 & 10,938 & 1 &, 001 & 8,140 \\
\cline { 2 - 8 } & Constant & $-9,895$ & 1,052 & 88,508 & 1 &, 000 &, 000 \\
\hline
\end{tabular}

a. Variable(s) entered on step 1: facility, service, ease access, ease of informastion.

RS facility variables with repeat visits obtained a p value of $0,000<\alpha=0.05$, so that $\mathrm{H} 0$ was rejected and $\mathrm{H} 1$ was accepted. It can be concluded that hospital facilities have an effect on revisiting outpatient installations

Hospital service variables with repeat visits obtained a value of $p$ value of $0.036<\alpha=0.05$, so that $\mathrm{H} 0$ was rejected and $\mathrm{H} 1$ was accepted. It can be concluded that hospital services have an effect on revisiting outpatient installations

The variables of ease of access with repeat visits obtained a value of $\mathrm{p}$ value of $0.023<\alpha=0.05$, so that $\mathrm{H} 0$ was rejected and $\mathrm{H} 1$ was accepted. It can be concluded that the ease of access has an effect on revisiting outpatient installations

The ease of information variable with a return visit obtained a value of $\mathrm{p}$ value of $0.001<\alpha=$ 0.05 , so that $\mathrm{H} 0$ was rejected and $\mathrm{H} 1$ was accepted. It can be concluded that the ease of information has an effect on revisiting outpatient installations.

The most dominant variable that influences the community in revisiting outpatient installations is hospital facilities with a $\mathrm{p}$ value of 0,000 . 


\section{DISCUSSION}

\section{Analyzing the Relationship Between Hospital Facilities by Conducting a Re-Visit to the Outpatient Installation of Praya Hospital}

Based on cross tabulation between hospital facilities by conducting a repeat visit to outpatient installation there were 147 respondents $(45.1 \%)$ stating that hospital facilities were not good where 129 respondents $(39.6 \%)$ did not reuse and 18 respondents (5.5\%). ) will reuse. While 179 respondents $(54.9 \%)$ stated that hospital facilities were good, where 15 respondents $(4.6 \%)$ stated that they would not reuse and 164 respondents $(50.3 \%)$ stated that they would make a repeat visit.

From the results of the statistical test, it was found that the hospital facility variable with a return visit obtained a value of $\mathrm{p}$ value of $0,000<\alpha=0.05$, so that $\mathrm{H} 0$ was rejected and $\mathrm{H} 1$ was accepted. It can be concluded that hospital facilities have an effect on revisiting outpatient installations. The results of the study found that the majority of respondents revealed that they re-used the visit by revealing 164 good facilities $(50.3 \%)$.

Appearance of service facilities will affect the attitudes and behavior of consumers to request services (kotler 2015). Which states that complete facilities, correct spatial planning can affect the attitude and behavior of buyers / patients such as feeling safe, comfortable and satisfied. Tjiptono (2012), states that service facilities affect consumer perceptions. The more complete the care facilities provided by the government and the private sector, the consumer demand for health services in some countries is increasing (Trisnantoro 2014).

Based on the results of the study that the hospital facilities had an effect on the return visit to the outpatient installation. The results showed that hospital facilities had an effect on revisiting, facilities in hospitals such as waiting rooms, places of worship, canteens, Canter ATMs and facilities provided by hospitals were very good and visitors were very comfortable. This shows that in the delivery of services, supporting facilities are considered good which can consist of facilities on site, decoration, supporting equipment, architectural suitability, and so forth. This is corroborated by Tjiptono (2012), stating service facilities affect consumer perceptions. And also expressed by Andri (2016), which states that the more complete the health care facilities, the higher utilization of health services. If this facility is easily accessible using available transportation, this facility will be widely used.

\section{Analyzing the Relationship Between Service Quality By Conducting a Re-Visit to the Outpatient Installation of Praya Hospital}

Based on cross tabulation between hospital services and repeat visits there were 142 respondents (43.6\%) stating that hospital services were not good, where 124 respondents $(38.0 \%)$ stated that they would not re-visit and 18 respondents (5.5\%). ) states that they will make a repeat visit. While 184 respondents $(56.4 \%)$ stated that hospital services were good, where 20 respondents $(6.1 \%)$ stated that they would not make a repeat visit and 164 respondents $(50.3 \%)$ stated that they would make a repeat visit.

The results showed that hospital service variables with repeat visits obtained a value of $p$ value of $0.036<\alpha=0.05$, so that $\mathrm{H} 0$ was rejected and $\mathrm{H} 1$ was accepted. It can be concluded that hospital services have an effect on revisiting outpatient installations. The results showed that most of the respondents stated that good hospital services were 164 respondents $(50.3 \%)$.

According to Garvin in Tjiptono (2012: 168) define service quality is defined as the expected level of excellence and control over the level of excellence to meet customer desires. Service quality is not seen from the point of view of the organizer or service provider, but is based on the perception of the community (customer) service recipient. Customers who consume and feel the services provided, so that they should assess and determine the quality of service. If the service received or felt is in accordance with what is expected, then the quality of service has a good and satisfying perception. If the service received exceeds customer expectations, then the quality of service is perceived as the ideal quality. Conversely, if the service received is lower than expected, then the quality of service is perceived poorly. Thus the good quality of service depends on the ability of service providers to meet the expectations of the community (service recipients) consistently. Based on the description of a number of opinions presented, the definition of service quality is the totality of characteristics of a service concept that covers all aspects of service, and the measure of service quality is to be able to satisfy customers or service recipients. 


\section{Analyzing the Relationship Between Ease of Access By Conducting a Re-Visit to the Outpatient Installation of Praya Hospital.}

Based on cross tabulation between ease of access and repeat visits there were 135 respondents (41.4\%) stating that access was difficult where 118 respondents $(36.2 \%)$ would not make a repeat visit and 17 respondents $(5.2 \%)$ stated that they would make a visit reset it. While 191 respondents $(58.6 \%)$ stated that the ease of easy access, where 26 respondents (8.0\%) stated that they would not make a repeat visit and 165 respondents $(50.6 \%)$ stated that they would make a repeat visit.

The results showed that the ease of access variable with a return visit obtained a value of $p$ value of $0.023<\alpha=0.05$, so that $\mathrm{H} 0$ was rejected and $\mathrm{H} 1$ was accepted. It can be concluded that the ease of access has an effect on revisiting outpatient installations. The results of the study showed that the majority of respondents revealed that they used a return visit by revealing 165 easy accesses $(50.6 \%)$.

Distance is how far the trajectory taken by the respondent goes to the health service area which includes the hospital, Puskesmas, Posyandu and others (Khudori 2012). Measures about the ease of difficulty of a location are achieved, one of which is stated by Mosely (2013), he states that accessibility of a place is a function of proximity to alternative destinations of utility, which is measured by indicators of time, distance and cost. Mileage to health services based on the 2010 Riskesdas report is classified into less than 1 kilometer $(<1 \mathrm{~km}), 1$ to 5 kilometers $(1-5 \mathrm{Km})$, more than five kilometers $(>5 \mathrm{~km})$. While travel time is classified as less than 15 minutes $(<15)$, between 16 to 30 minutes $\left(16^{\prime}-30\right.$ ') and between 31 to 60 minutes $\left(31^{\prime}-60^{\prime}\right)$ and more than 60 minutes (60'). American Thoracic. (2014) concluded that the factor of proximity of health services to residential homes became the first order factor for consumer demand in the utilization of health services. Henny (2013) showed that the chances of Jamkesmas participants who were close to reaching health facilities were 2,930 times greater than those of far Jamkesmas participants who reached health facilities.

\section{Analyzing the Relationship Between Ease of Information By Conducting a Re-Visit to the Outpatient Installation of Praya Hospital}

Based on the cross tabulation between the ease of information and revisiting, 116 respondents (35.6\%) stated that information was difficult, where 111 respondents $(34.0 \%)$ stated that they would not make a repeat visit and 5 respondents $(1.5 \%)$ stated that they would make a repeat visit. While 210 respondents (64.4\%) stated that the ease of information was easy, where 33 respondents (10.1\%) stated that they would not make a repeat visit and 177 respondents $(54.3 \%)$ stated that they would make a repeat visit.

The results showed that the ease of information variable with a return visit obtained a value of $p$ value of $0.001<\alpha=0.05$, so that $\mathrm{H} 0$ was rejected and $\mathrm{H} 1$ was accepted. It can be concluded that the ease of information has an effect on revisiting outpatient installations. The results of the study found that the majority of respondents revealed that they used re-visit by expressing easy information convenience as many as 165 respondents $(50.6 \%)$.

Ease of information is the information obtained by patients is very clear and easily obtained related to hospital services. Service Package is defined as a combination of goods and services with information provided through the existing environment. This combination consists of five features and service experience as the core (Fauziah, Rahmania, 2014). Accurate information is a feature that contains information about the information provided or owned by the hospital is the latest information and whether the information is true. Timely information contains information about the emergency warnings, promotions, and timely notifications, and useful information about whether the services provided are useful to customers. Attitudes in behavior are formed in a communication process whereby the existence of a cognitive informative communication process will arise attitudes that consider all relevant information that already exists in accordance with one's abilities and intelligence in terms of analyzing, the accuracy of instincts and awareness of the needs that are needed in certain conditions and in the next stage someone takes action in accordance with the motivational drive that is controlled by attitudes and emotions where similar actions are repeated so that this can be said to be behavior in life (Liliweri, 2017). 


\section{Analyzing the Most Dominant Factors Affecting the Community in Conducting a Re-Visit at the Swamp Installation in Praya Hospital}

The results obtained by multivariate analysis with logistic regression simultaneously showed a significant result of 0.031. It can be concluded that all independent variables (hospital facilities, hospital services, ease of information, and ease of access (distance, transportation)) jointly affect the dependent variable (Make a repeat visit to the outpatient installation) The table shows the Cox and Snell $\mathrm{R}$ coefficients Square R 0.583 or $58.3 \%$ and Nagelkerke R Square coefficient 0.781 or $78.1 \%$. Nagelkerke $\mathrm{R}$ Square coefficient of $78.1 \%$ means that the independent variables (hospital facilities, hospital services, ease of information, and ease of access (distance, transportation)) affect the dependent variable (Make a return visit to outpatient installation) in general by $78,1 \%$ is $21.9 \%$ influenced by other factors not included in the model test. Logistic regression test results obtained hospital facilities $(p=0,000)$, hospital services $(p=0.036)$, ease of access $(p=0.023)$, and ease of information $(p=0.001)$ affect the return to outpatient installations, and the most variable dominant influence is hospital facilities.

Buyer's behavior can be used as basic tips to connect the quality of service satisfaction and interest in consumer behavior to use the same service if they are satisfied with the service they receive. Buyers who are satisfied with the quality of the product they receive will buy the product again. The interest in consumer behavior to buy or use services from the same service provider is strongly influenced by the experience of satisfaction with the services provided previously. All users who are familiar with a particular product or service are not always the same, some due to the selection of unique alternatives. Some who are related in terms of likes or dislikes, reject but actually like and some fanatics who never consider other options. Loyalty can be surprising and cannot be questioned. They believe that using a brand and different habits will mean the risk of failure (Azwar, 2010). Loyalty is a measure of the desire to use or buy a service for a particular service seller because they feel there is satisfaction in their service. Loyal customers are customers who get high satisfaction so that it is very elastic towards price changes, and believes in the seller's reputation. Loyal customers are customers who will repurchase their services. For customers with low levels of satisfaction, they are more easily moved and are very rigid about price changes.

\section{CONCLUSION}

The results of the study were obtained Hospital facility variables with repeat visits obtained $\mathrm{p}$ value of $0,000<\alpha=0.05$, so that $\mathrm{H} 0$ was rejected and $\mathrm{H} 1$ was accepted. It can be concluded that hospital facilities have an effect on revisiting outpatient installations.

The results of the study were obtained RS service variables with repeat visits obtained $p$ value of $0.036<\alpha=0.05$, so that $\mathrm{H} 0$ was rejected and $\mathrm{H} 1$ was accepted. It can be concluded that hospital services have an effect on revisiting outpatient installations.

The results of the study obtained variables of ease of access with repeat visits obtained by the value of $\mathrm{p}$ value of $0.023<\alpha=0.05$, so that $\mathrm{H} 0$ is rejected and $\mathrm{H} 1$ is accepted. It can be concluded that the ease of access has an effect on revisiting outpatient installations.

The results of the study showed that the ease of information variable with a return visit obtained a value of $\mathrm{p}$ value of $0.001<\alpha=0.05$, so that $\mathrm{H} 0$ was rejected and $\mathrm{H} 1$ was accepted. It can be concluded that the ease of information has an effect on revisiting outpatient installations.

Logistic regression test results obtained hospital facilities $(p=0,000)$, hospital services $(p=$ 0.036), ease of access $(p=0.023)$, and ease of information $(p=0.001)$ affect the return to outpatient installations, and variables the most dominant influence is hospital facilities.

\section{REFERENCE}

Alamsyah. 2017. Faktor-faktor yang mempengaruhi pasien dalam pemanfaatan layanan rawat jalan di rumah sakit universitas hasanuddin. Skipsi. Makkasar: Fakultas kesehatan masyarakat Universitas hasanuddin makkasar

American Thoracic Society.2014. Standardization of spirometry 2012 update. Am Rev Respir Dis 2012;136:1285-98. 
Anggraeni, Nila Vicky. 2013. Faktor-Faktor yang Mempengaruhi Pengambilan Keputusan Masyarakat untuk Memilih Jasa Pelayanan Kesehatan di Rumah Sakit PKU Muhammadiyah Simo Kabupaten Boyolali. Skripsi. Surakarta: Fakultas Ilmu Kesehatan Universitas Muhammadiyah Surakarta

Azwar dkk. 2010. Pengantar Administrasi Kesehatan. Jakarta:Bina Rupa Aksara

Dumpapa, Y. 2010. Hubungan Lokasi, Biaya, Personil dan Informasi rumah sakit dengan keputusan memilih rawat inap di RSUD Bitung. Manado: Program Pasca Sarjana Universitas Sam Ratulangi

Fauzia, Rahmania. 2014. Faktor-faktor yang Berhubungan dengan Keputusan Pemilihan Tempat Persalinan Pasien Poliklinik Kandungan dan Kebidanan di Rumah Sakit Ibu dan Anak Kemang Medical Care Tahun 2014. Skripsi. Jakarta: Fakultas Kedokteran dan Ilmu Kesehatan Universitas Islam Negeri Syarif Hidayatullah

Henny. 2013. Faktor-Faktor yang Mempengaruhi Keputusan Masyarakat dalam Memilih Berobat Rawat Inap Pada Rumah Sakit Permata Blora. Skripsi. Surakarta :Universitas Negeri Sebelas Maret.

Institute of Medicine, Committee on Quality of Health Care in America. 2012. Institute of Medicine Reports Composite Summary. Washington DC: National Academy Press

Kepmenkes No.129 tahun 2012 tentang Standar Pelayanan Minimal RS

Khudori. 2012. Analisis Faktor-Faktor yang Mempengaruhi Keputusan Pemilihan Tempat Persalinan Pasien Poliklinik Kandungan dan Kebidanan Rumah Sakit IMC Bintaro tahun 2012. Tesis. Depok: Fakultas Kesehatan Masyarakat Universitas Indonesia

Kotler,p., Boom, P.N.,2015. Teknik dan strategimemasarkan jasa profesial. Intermedia, Jakarta: Penerbit PT Prehallindo

Kotler, Philip. 2015. Manajemen Pemasaran: Analisis, Perencanaan, implementasi dan Kontrol, edisi Sebelas. Alih Bahasa, Hendra Teguh. Jakarta: Penerbit PT Prenhallindo

Liliweri, Alo. 2017. Dasar-Dasar Komunikasi Kesehatan. Yogyakarta : Pustaka Pelajar.

Maslina. (2011). Hubungan persepsi pasien tentang kualitas pelayanan dengan minat kunjungan ulang pasien rawat jalan di RS Zahirah Jakarta tahun 2011.( Skripsi tidak dipublikasikan). FKM UI, Depok.

Suryadi, Sofjan, 2010, Biaya atau Kepuasan Pasien?, www.Pdpersi.co.id

Tjiptono, Fandy. 2012. Pemasaran Jasa. Edisi pertama. Malang : Banyumedia publishing.

Trisnantoro. 2014. Memahami Penggunaan Ilmu Ekonomi dalam Manajemen Rumah Sakit. Yogyakarta: Gajah Mada University Press. 